\title{
Stimulation of Defense Enzymes in Tomato (Solanum lycopersicum L.) and Chilli (Capsicum annuum L.) in Response to Exogenous Application of Different Chemical Elicitors
}

\author{
Y.S.M. Asanka Indunil Kumari, A. Vengadaramana* \\ Department of Botany, Faculty of science, University of Jaffna, Sri Lanka
}

\begin{abstract}
Copyright $(\mathcal{C} 2017$ by authors, all rights reserved. Authors agree that this article remains permanently open access under the
\end{abstract} terms of the Creative Commons Attribution License 4.0 International License

\begin{abstract}
The objective of this study was to evaluate the response to exogenous application of different chemical elicitors on the stimulation of defense enzymes such as chitinase, peroxidase, phenylalanine ammonialyase (PAL) and polyphenoloxidase (PPO) in tomato and chilli plants leaves tissues. Chemical elicitors are compounds, which activate chemical defense systems in plants. Various biosynthetic pathways are activated by chemical elicitors in plants depending on the elicitors used. Two times exogenous application of $200 \mathrm{ppm}$ of salicylic acid (SA), ascorbic acid (AA), jasmonic acid (JA) and $\mathrm{H}_{2} \mathrm{O}_{2}$ and ethanol (1 mL of 95\% ethanol in $1 \mathrm{~L}$ distilled water) induced the four defense enzymes production in chilli and tomato plants leaves tissues and significantly reduced viral disease incidence in chilli plants compared to control. SA at 200 ppm enhanced significantly chitinase, peroxidase, PAL and PPO enzymes in leaves tissues of tomato plants. Tomato plants treated with chemical elicitors and control did not show any disease symptoms.
\end{abstract}

Keywords Ascorbic Acid, Chilli, Jasmonic acid, Peroxidase, Salicylic Acid, Tomato

\section{Introduction}

Chilli (Capsicum annuum L.) is one of the important cash crops grown in Jaffna district, Sri Lanka belonging to family of Solanaceae. It has become an essential ingredient in Sri Lankan meals. The chilli is one of the most important vegetable as well as spice crops around the world, valued for its aroma, taste, flavor and pungency [6]. Besides traditional uses, it is also being used in pharmaceuticals, cosmetics and beverages [38]. Tomato (Solanum lycopersicum L.) is one of the most widely cultivated vegetable crops in the world. It is an important cash crop for medium scale commercial farmers in Jaffna district of Sri Lanka. However, both quantity and quality of tomato and chilli are affected by many diseases, pests, nutrient deficiencies, and due to climatic and environmental conditions. It has become a serious threat to subsistence and commercial agriculture.

Several studies proved that exogenous application of different elicitors are useful to enhanced resistance to herbivore challenge and induce the expression of defense related genes [21, 18]. Exogenous or endogenous factors could affect host physiology, lead to rapid and coordinated activation of defense-gene in plants normally expressing susceptibility to pathogen infection [23, 26]. Studies have indicated remarkable similarities between the defense mechanisms triggered by general elicitors and the innate immunity of animals, and it is tempting to speculate that the recognition of general elicitors subsequently leads to plant innate immunity [27]. Elicitors act as signal compounds at low concentrations, providing information for the plant to trigger defense, distinguishing elicitors from toxins, which may act only at higher concentrations and / or affect the plant detrimentally without active plant metabolism [7]. This induced resistance to pathogens can be achieved by the application of various abiotic agents (chemical inducers) such as salicylic acid, potassium salts and sorbic acid [1, 3]. The present study was conducted to evaluate the defense enzymes stimulation by the application of different chemical elicitors on tomato and chilli plants.

\section{Materials and Methods}

\section{Application of Chemical Elicitors}

Seeds of tomato (variety KC1) and chili (variety MI2) were planted separately in plastic pots with $20.5 \mathrm{~cm}$ height 
and $25.3 \mathrm{~cm}$ diameter. A rate of 2 plants/plastic pot was allowed to grow. Pots were arranged according to a completely randomized design (CRD) with six replicates per treatment. First foliar application of six treatments (Table1) were made using hand sprayer to plants at the 4-leaf stage and second application was made after 40 days of first application. A separate set of pots planted with tomato and chili separately but not treated with chemicals and water was maintained as control. Plants were maintained in the plant house at the Department of Botany, Faculty of Science, University of Jaffna, Sri Lanka.

Table1. Treatments

\begin{tabular}{|c|c|c|}
\hline Treatments & Chemical elicitor & Quantity \\
\hline Treatment 1 (T1) & Salicylic acid & $200 \mathrm{ppm}$ \\
\hline Treatment 2 (T2) & Ascorbic acid & $200 \mathrm{ppm}$ \\
\hline Treatment 3 (T3) & Jasmonic acid & $200 \mathrm{ppm}$ \\
\hline Treatment 4 (T4) & Ethanol (95\%) & $\begin{array}{c}1 \mathrm{~mL} \text { in 1 L } \\
\text { Distilled water }\end{array}$ \\
\hline Treatment 5 (T5) & $\mathrm{H}_{2} \mathrm{O}_{2}$ & $200 \mathrm{ppm}$ \\
\hline Treatment 6 (T6) & Tap water & - \\
\hline
\end{tabular}

\section{Disease Incidence}

Plants were grown in an open green house, no pathogen was inoculated artificially. Common viral infection symptoms such as, chlorotic, necrotic, curling, mottling, stunting symptom were observed. The plants were monitored weekly after treatments were applied by recording number of leaves showing disease or damage out of total number of leaves of chilli and tomato plants.

\section{Sample Collection for Enzyme Assay}

Leaf samples were collected from tomato and chilli plants of all treatments and stored at $-20{ }^{\circ} \mathrm{C}$ immediate after detachment from the plants. The frozen plant leaf samples were ground in liquid nitrogen using separate mortars and pestles. The finely ground samples were stored in eppendorf tubes at $-20{ }^{\circ} \mathrm{C}$ until the assay of defense enzymes.

\section{Assay of Defense Enzymes}

\section{Assay of Chitinase}

Ground leaf sample $(0.5 \mathrm{~g})$ was mixed with $1 \mathrm{~mL}$ of $0.1 \mathrm{M}$ sodium acetate buffer ( $\mathrm{pH} 5.0$ ) and the mixture was vortexed for $3 \mathrm{~min}$. Then sample was centrifuged at 13,000 rpm for 15 min. Volume of $0.4 \mathrm{~mL}$ of the supernatant was mixed with $0.2 \mathrm{~mL}$ of $0.1 \mathrm{M}$ sodium acetate buffer (pH 5.0) and $0.2 \mathrm{~mL}$ of chitin azure. Then the samples were incubated at $40{ }^{\circ} \mathrm{C}$ for $10 \mathrm{~min}$. An aliquot of $0.2 \mathrm{~mL}$ of $2 \mathrm{~N}$ hydrochloric acid was mixed with the sample and kept on ice for $10 \mathrm{~min}$. Once again sample was centrifuged at 13,000 rpm for $15 \mathrm{~min}$ and the supernatant was used to read the absorbance at $575 \mathrm{~nm}$ [2].

\section{Assay of Peroxidase}

Ground leaf sample $(0.5 \mathrm{~g})$ was mixed with $1.5 \mathrm{~mL}$ of 0.1 $\mathrm{M}$ sodium phosphate buffer $\mathrm{pH} 7.0$ at $4{ }^{\circ} \mathrm{C}$. Then the mixture was centrifuged at $10,000 \mathrm{rpm}$ for $20 \mathrm{~min}$ and the supernatant was used as the enzyme source. The reaction mixture consisted of $1.5 \mathrm{~mL}$ of $0.05 \mathrm{M}$ pyrogallol, $0.5 \mathrm{~mL}$ of enzyme dilute and $0.5 \mathrm{~mL}$ of $1 \% \mathrm{H}_{2} \mathrm{O}_{2}$. The changes in absorbance at $420 \mathrm{~nm}$ were recorded at $30 \mathrm{~s}$ intervals for $3 \mathrm{~min}$. The enzyme activity is expressed as changes in the absorbance $\min ^{-1} \mathrm{~g}^{-1}$ leaf tissue [17].

\section{Assay of Phenylalanine Ammonia Lyase (PAL)}

An aliquot of $1 \mathrm{~mL}$ of $0.1 \mathrm{M}$ phosphate buffer was added to ground plant sample $(0.5 \mathrm{~g})$. The samples were centrifuged at $10,000 \mathrm{rpm}$ for $20 \mathrm{~min}$. The supernatant was used as the enzyme source. Volume of $0.5 \mathrm{~mL}$ of $0.1 \mathrm{M}$ phosphate buffer, $0.1 \mathrm{~mL}$ enzyme source and $0.4 \mathrm{~mL}$ de-ionized water were placed in a test tube. The reaction was initiated by the addition of $1 \mathrm{~mL}$ of $0.1 \mathrm{M}$ L-Phenylalanine solution and incubated for $30 \mathrm{~min}$ at $37^{\circ} \mathrm{C}$. The reaction was stopped by adding $0.5 \mathrm{~mL}$ of $1 \mathrm{M}$ Trichloro acetic acid. A blank reading was taken by adding $0.5 \mathrm{~mL}$ phosphate buffer and $0.5 \mathrm{~mL}$ de-ionized water. The rest of the procedure was followed for the blank test was similar to the test with sample extract. The absorbance was measured at $290 \mathrm{~nm}$. A standard graph was prepared for trans-cinnamic acid [9].

\section{Assay of Polyphenol Oxidase (PPO)}

PPO activity was determined as per the procedure given by Mayer et al. [24]. Ground plant sample (0.5g) was mixed with $1.5 \mathrm{~mL}$ of $0.1 \mathrm{M}$ sodium phosphate buffer (pH7.0) and centrifuged at 10,000 rpm for $20 \mathrm{~min}$. The supernatant was used as the enzyme source. The reaction mixture consisted of $200 \mu \mathrm{L}$ of the enzyme extract and $1.5 \mathrm{~mL}$ of $0.1 \mathrm{M}$ sodium phosphate buffer (pH7.0). To start the reaction, $200 \mu \mathrm{L}$ of $0.01 \mathrm{M}$ catechol was added. The changes in absorbance at $495 \mathrm{~nm}$ were recorded at $10 \mathrm{~s}$ intervals for $1 \mathrm{~min}$. The activity was expressed as changes in absorbance $\min ^{-1} \mathrm{~g}^{-1}$ leaf tissue.

\section{Data Analysis}

Data were analyzed by variance (ANOVA) using a SAS statistical package (version9.1.3) and mean separation was done by Least Significance Difference (LSD).

\section{Results and Discussion}

Chilli plants treated with chemical elicitors and distilled water and control showed viral diseases such as little leaf and leaf puckering (Figure1) but percentage infected leaves varied among treated plants and control (Figure 2). There was a significant reduction in viral diseases development in chilli plants when they were treated with chemical elicitors such as salicylic cacid (SA), ascorbic acid (AA), jasmonic acid (JA), ethanol and $\mathrm{H}_{2} \mathrm{O}_{2}$ when compared to plants treated 
with distilled water and control. There was no viral disease incidents observed in tomato plants (Treated and Control). Chilli plants are infested by more than 21 insects and non-insect pests [35, 4], and some herbivores insect such as aphid, thrips and mites also acts as a vector for the transmission of plant disease causing viruses [37].

The higher percentages of disease incidence were reported by Treatment 6 and control were not significantly different in terms of percentage of infected leaves. The lower percentage of disease incidence shown by treatments Treatment 1 , Treatment 2 and Treatment 3 hence chemical elicitors SA, AA and JA reduce the disease incidents in chilli plants by induce the expression of defense related genes at $200 \mathrm{ppm}$. Next to the treatments Treatment 1, Treatment 2 and Treatment 3 there were viral disease reduction observed in treatments Treatment 4 and Treatment 5 (Figure 2).
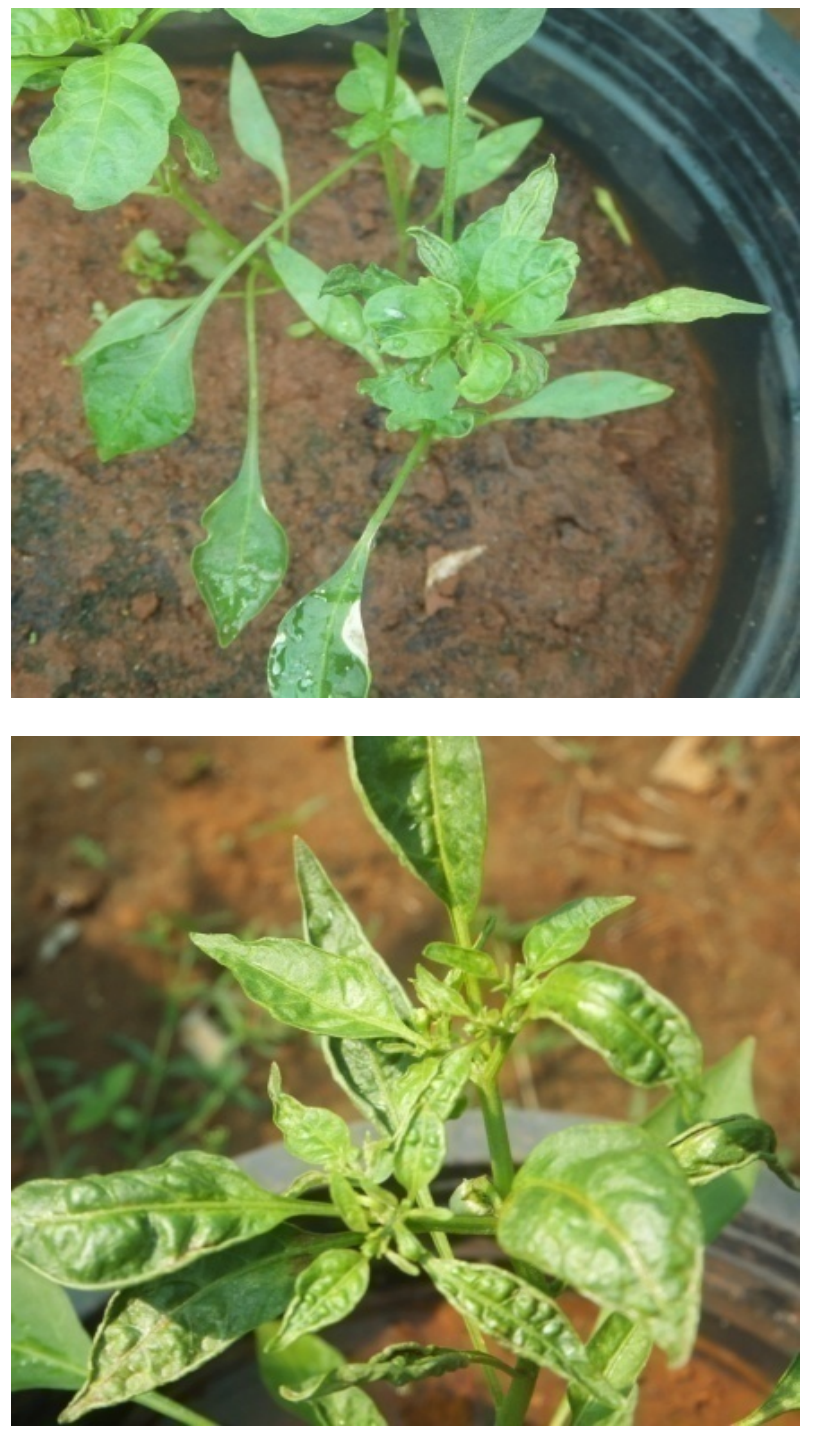

Figure 1. Disease symptoms showing chilli plants

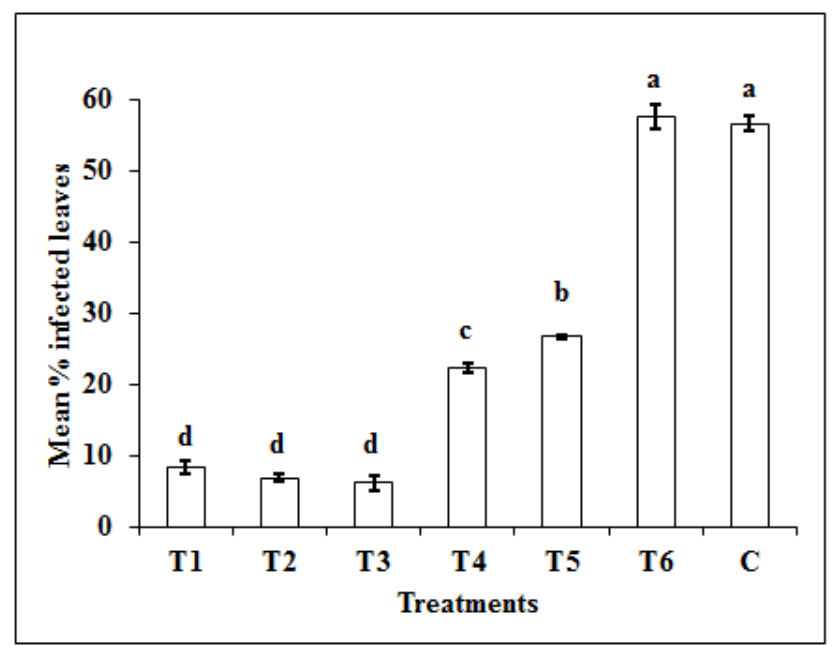

Mean followed by same letters are not significantly different by LSD at 5\% level

Figure 2. Effect of SA (T1), AA (T2), JA (T3), Ethanol 95\% (T4) , $\mathrm{H}_{2} \mathrm{O}_{2}$ (T5), Distilled water (T6) and control (C) in viral disease incidence in terms of \% leaves infected on chilli plants.

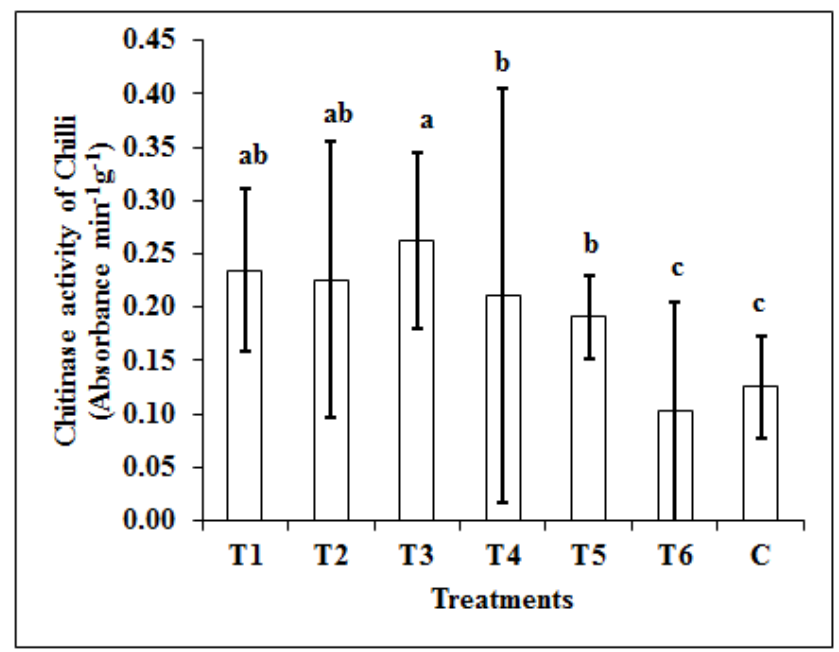

Mean followed by same letters are not significantly different by LSD at $5 \%$ level

Figure 3. Response of catalase enzymatic activity in chilli leaf tissues treated with chemical elicitors, distilled water and control.

The results from the statistical analysis showed significant differences among treatments and control. It was observed that different elicitors exerted a different effect on the chitinase on chilli and tomato plants (Figure 3 and 4). Chitinase degrades chitin, a major component of pathogen cell walls [16]. Chitinase may affect insects by damaging chitin-based structures such as the peritrophic membrane that provides a physical barrier to ingested pathogens and other substances that pose a hazard to the insect. Chitinases can also act as $\alpha$-amylase inhibitors and interfere with digestion of plant parts [5]. Induction of chitinase activity may interfere with insect development, feeding and growth facilitate microbial infection, and finally cause death [34]. Wang et al. [39] reported that $100 \%$ larval mortality of the grain beetle, Oryzaephilus mercator, six days after feeding on $2 \%$ chitinase obtained from transgenic tobacco. 


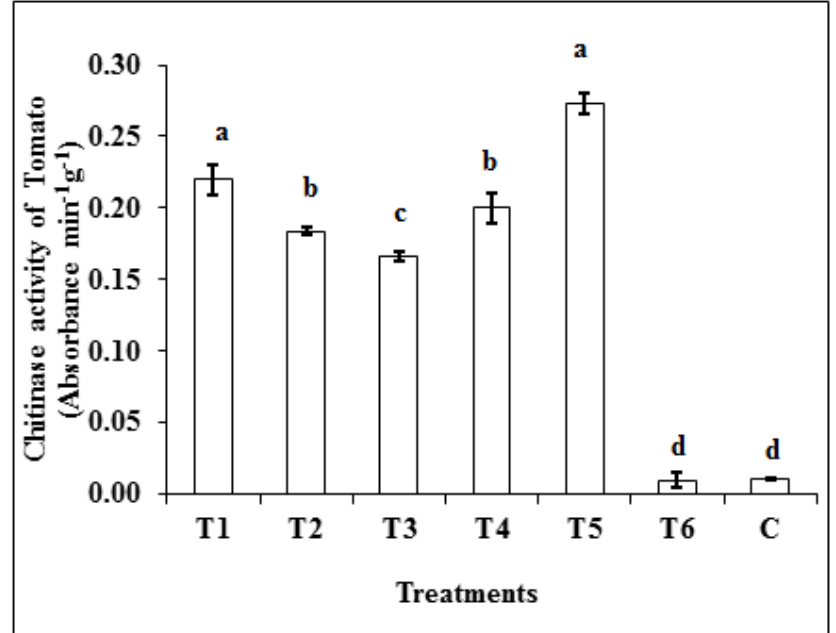

Mean followed by same letters are not significantly different by LSD at $5 \%$ level

Figure 4. Response of chitinase enzymatic activity in tomato leaf tissues treated with chemical elicitors, distilled water and control.

Peroxidases participate in a variety of defense mechanisms [20], to ameliorate oxidative burst a common event in defense response [19]. Peroxydase activity of tomato tissue was significantly different among treatments and control (Figure 5). Though there was no significant variation among treatments and control in chilli leaf tissues in the activity of peroxidase enzyme. Peroxoydase is one of the enzymes contributing to plant resistance to pathogens [33]. Plant peroxidase activity seems to be under the strict control depending on the development stage and the environmental stimulus [15]. Maksimov et al. [22] reported that the activation of peroxidase is correlated to the defense responses of fruit in presence of pathogens. Peroxidases are induced in tomato plants following pathogen and insect damage.

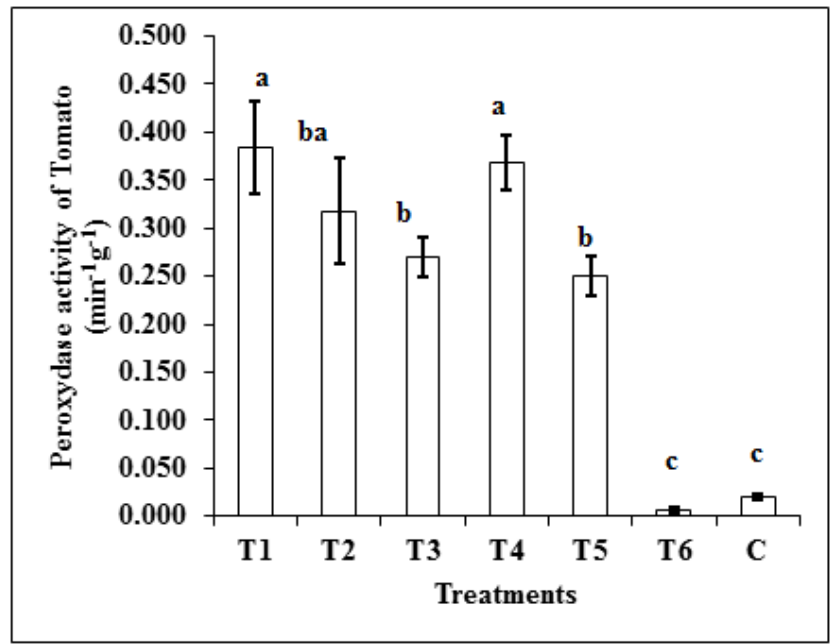

Mean followed by same letters are not significantly different by LSD at $5 \%$ level

Figure 5. Response of peroxydase enzymatic activity in tomato leaf tissues treated with chemical elicitors, distilled water and control.
Peroxidases are involved in production and polymerization of phenolics, lignification, and hypersensitive responses, limiting the possibility of disease spread [8].

PAL activity in tomato tissues differed significantly among different treatments and control (Figure 6). In chilli leaf tissues, no significant difference was observed in PAL activity among treatments and control.

A significant difference was observed in PPO activity among treatments and control in tomato leaf tissues (Figure 7) but no significant difference was observed in PPO activity among treatment and control in chilli plants leaves tissues.

The levels of defense related enzymes (PAL, POX, PPO etc.) play a crucial role with respect to the degree of host resistance [30]. These are highly important in the defense mechanism against pathogens, by increasing antimicrobial activity and may be directly involved in controlling pathogen development [25]. Increase in these defense related enzymes also cause reduction in disease severity [14, $10,36]$.

When SA, AA, JA, ethanol $95 \%$ and $\mathrm{H}_{2} \mathrm{O}_{2}$ were used as elicitors, statistically significant increase of the activities of chitinase, PAL, peroxydase and PPO were observed in the leaf tissues of chilli and tomato plants. The influence of jasmonic acid on the mechanisms of plant resistance to arthropods is associated with the products of induced expression of numerous genes [32, 28]

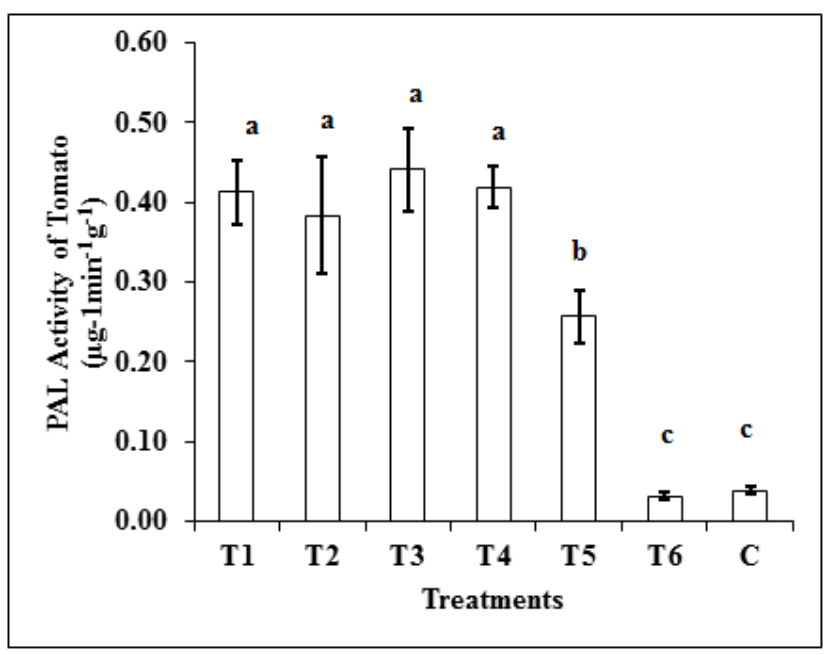

Mean followed by same letters are not significantly different by LSD at $5 \%$ level

Figure 6. Response of PAL enzymatic activity in tomato leaf tissues treated with chemical elicitors, distilled water and control. 


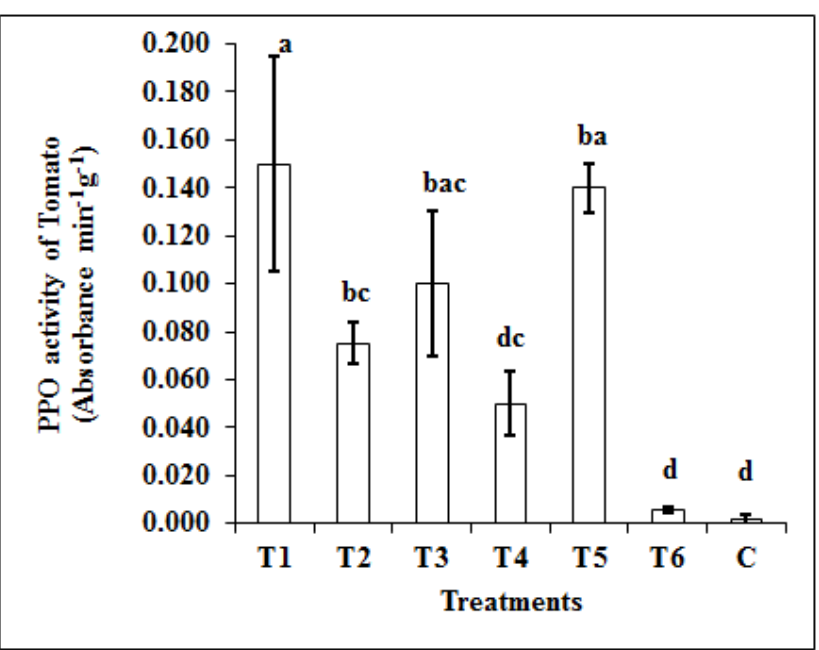

Mean followed by same letters are not significantly different by LSD at $5 \%$ level

Figure 7. Response of PPO enzymatic activity in tomato leaf tissues treated with chemical elicitors, distilled water and control.

Jasmonic acid enhanced resistance by regulating expression of defense related genes [21, 18]. Moreover, JA is also involved with different physiological activities such as seed germination, tuber formation, tendril coiling, leaf senescence, stomata opening, fruit ripening and root growth, and also plays crucial roles in plant defense responses against insect damage and microbial pathogens attack [40]. Systemic resistance mechanisms are induced in crop plants by treatment with chemical inducer salicylic acid [13, 31].

In chilli leaf tissues, no significant difference were observed in peroxydase, PAL and PPO activity among treatments and control. All the treatments (1, 2, 3, 4 and 5) prduced defence enzymes because of the activation of defense system in chilli plants by exogenous chemical elecitors. Due to the viral infection plants treated with distilled water and control also produced four defense enzymes. An important finding from our study revealed that all tested chemical inducers had positive effects on plant disease control in chilli plants. Tomato plants did not show symptoms it could be the tomato seeds are resistant to disease or the environmental conditions are not suitable for development of disease in tomato plants. Elicitors can be used to activate plant defensive systems at desired times; however, generally they should be applied prior to having a pest-problem so that the plant will have the best opportunity for resisting pests [11]. Elicitors will probably not be effective in all plants since defensive systems vary with plant variety.

Similar results also gave evidence to the role of $\mathrm{H}_{2} \mathrm{O}_{2}$ in activation of an array of host defense mechanisms including induced activity of enzymes as peroxidase and chitinase accompanied by a significant increase in the lignin and suberin content [29]. Moreover, $\mathrm{H}_{2} \mathrm{O}_{2}$ plays also an essential role in lignifications, and cross linking of cell wall proteins with phenolic acids, leading to reinforcement of cell walls at the site of pathogen attack positively influences the local and systemic accumulation of SA that is correlated with the enhancement of peroxidase activity [12].

\section{Conclusions}

Two time exogenous application of SA, AA, JA, ethanol $95 \%$ and $\mathrm{H}_{2} \mathrm{O}_{2}$ showed stress symptoms indifferent defense enzymes activities (Chitinase, Peroxidase, phenylalanine ammonia lyase and polyphenol oxidase) in chilli and tomato plant but in chilli plants reduced percentage of viral disease incidence and severity.

\section{Acknowledgments}

Financial assistance by University of Jaffna, Sri Lanka (Jaffna university research grant 2015) is acknowledged.

\section{REFERENCES}

[1] Abdel-Monaim, M. F. (2010). Induced systemic resistance in tomato plants against Fusarium wilt disease. 253-263pp. In Proceedings of the $2^{\text {nd }}$ Minia Conference for Agriculture and Environmental Science, 22-25Minia, Egypt.

[2] Ahokas, H. and Naskali, L. (1990). Variation of $\alpha$-amylase, $\beta$-amylase, $\beta$-glucanase, pullulanase, proteinase and chitinase activity in germinated samples of the wild progenitor of barley. J. Inst. Brew, 96, 27-31.

[3] Akram, W. and Anjum, T. (2011). Use of bioagents and synthetic chemicals for induction of systemic resistance in tomato against diseases. Int. Res. J. Agric. Sci. Soil Sci, 1, 286-292.

[4] Arogundade, O., Balogun, O. S. and Kareem, K. T. (2012). Occurrence and distribution of pepper veinal mottle virus and cucumber mosaic virus in pepper in Ibadan, Nigeria. Virol. J, 9, 1-4.

[5] Ary, M. B., Richarson, M., and Shewary, P. R. (1989). Purification and characterization of an insecta-amylase inhibitor/endochitinase from seeds of Job'stears (Coixlachryma-jobi). Biochim. Biophys. Acta, 993, 260-266.

[6] Awanga, N. A., Robiul, I. M., Ismaila, M. R., Zulkaramia, B. and Omarc, D. (2013). Effectiveness of different elicitors in inducing resistance in chilli (Capsicum annuum L.) against pathogen infection. Scientia Horticulturae,164, 461-465

[7] Boller, T, (1995). Chemoperception of microbial signals in plant cells. Annual Review of Plant Physiology and Plant Molecular Biology, 46, 189-214.

[8] Bowles, D. J. (1990). Defense-related proteins in higher plants. Annu. Rev. Biochem., 59, 873-907.

[9] Bruske, C. H. (1980). Phenylalanine ammonia lyase activity in tomato roots infected and resistant to the root-knot nematode (Meloidogyne incognita). Physiol. Pl. Path., 16, 409-414. 
[10] Cao, J., Zeng, K. and Jiang, W. (2006). Enhancement of post-harvest disease resistance in Yalipear (Pyrus bretschneideri) fruit by salicylic acid sprays on the trees during fruit growth. Eur. J. Plant Pathol., 114, 363-370.

[11] Ciba-Geigy. (1995). CGA 245704. A plant activator for disease protection.Technical Data heet.Basle, Switzerland.

[12] Copes, W. E. (2009). Concentration and intervals of hydrogen dioxide applications to control Puccinia hemerocallis on daylily. Crop Protection, 28, 24-29.

[13] DeMeyer, G., Capieau, K., Audenaert, K., Buchala, A., Metraux, J.P. and Hotfite, M. (1999). Nanogram amounts of salicyclic acid produced by the rhizobacterium Pseudomonas aeruginosa 7NSK2 activate the systemic acquired resistance path way in bean. Molecular Plant Microbes Interact., 12, 450-458.

[14] Eckardt, N. A. (2004). Amino transferases confer "Enzymatic resistance" to downy mildew in melon. Plant Cell, 16, 1-3.

[15] Gadea, J., Conejero, V., Vera, P. (1999). Mol. Gen. Genet., 262, 212.

[16] Graham, L. S., and Sticklen, M. B. (1994). Plant chitinases. Can. J. Bot. 72, 1057-1083.

[17] Hammerschmidt, R., Nuckles, E. M. and Kuc', J. (1982). Association of enhanced peroxidase activity with induced systemic resistance of cucumber to Colletotrichum lagenarium. Physiol. Plant Pathol, 20, 73-82.

[18] Howe, G. A. and Jander, G. (2008). Plant immunity to insect herbivores. Annu. Rev. Plant Biol., 59, 41-66.

[19] Lamb, C., and Dixon, R. A. (1997). The oxidative burst in plant disease resistance. Annual Review of Plant Physiology and Plant Molecular Biology, 48, 251-75.

[20] Liu, Y., Pan, Q. H., Yang, H. R., Liu, Y. Y. and Huang, W. D. (2008). Relationship between $\mathrm{H}_{2} \mathrm{O}_{2}$ and Jasmonic acid in Pea leaf wounding response. Russ. J. Plant Physiol., 55(6), 851862.

[21] Lorenzo, O. and Solano, R. (2005). Molecular players regulating the jasmonate signaling network. Curr. Opin. Plant Biol., 8, 532-540.

[22] Maksimov, I. V, Cherepanova, E. A. and Khairullin, R. M. (2003). Chitin-specific peroxidases in plants. Biochemistry, $68,111-115$.

[23] Mandal, S., Mallick, N. and Mitra, A. (2009). Salicylic acid-induced resistance to Fusarium oxysporum f. sp. Lycopersici in tomato. Plant Physiol. Biochem., 47, 642-649.

[24] Mayer, A. M., Harel, E. and Shaul, R. B. (1965). Assay of catechol oxidase, a critical comparison of methods. Phytochemistry, 5, 783-789.

[25] Melo, G. A., Shimizu, M. M. and Mazzafera, P. (2006). Polyphenoloxidase activity in coffee leaves and its role in resistance against the coffee leaf miner and coffee leaf rust. Phytochem., 67, 277-285.

[26] Metwally, M. M. (2004). Resistance induction against disease of fababean crop. PhD Thesis, Fac. Of Agric., Cairo University, Egypt, 94pp.

[27] Nürnberger, T. and Brunner, F. (2002). "Innate immunity in plants and animals: emerging parallels between the recognition of general elicitors and pathogen-associated molecular patterns”. Current Opinionin Plant Biology, 5(4), 318-324.

[28] Pena-Cortès, H., Barrios, P., Dorta, F., Polanco, V., Sanchez, C., Sanchez, E., RamirezI. (2005). Involvement of Jasmonic acid and derivatives in plant responses to pathogens and insects and in fruit ripening. J. Plant Growth Regul., 23(3), 246-260.

[29] Quiroga, M., Guerrero, C., Botella, M.A., Barcelo, A., Amaya, I., Medina, M., Alonso, F. J., DeForchetti, S. M., Tigier, H. and Valpuesta, V. (2000). A tomato peroxidase involved in the synthesis of lignin and suberin. Plant Physiol., 122, 11191127.

[30] Ralph, S., Park, J. Y., Bohlman, N. J. and Mansfield, S. D. (2006). Dirigent proteins in conifer defense: gene discovery, phylogeny, and differential wound and insect-induced expression of a family of DIR and DIR-like genes in spruce (Piceaspp.). Plant Mol. Biol., 60, 21-40.

[31] Sakamoto, K., Tada, Y., Yokozeki, Y., Akari, H., Hayashi, N., Fujimura, T. and Ichikawa, N. (1999). Chemical induction of disease resistance in rice correlated with the expression of a gene encoding a nucleotide binding site and leucine-rich repeats. Plant Molec. Biol., 40, 847-855.

[32] Schenk, P. M., Kazan, K., Wilson, I., Anderson, J. P., Richmond, T., Somerville, S.C. and Manners, J. M. (2000). Coordinated plant defense responses in Arabidopsis revealed by microarray analysis. Proc. Natl. Acad. Sci. USA., 97, 11655-11660.

[33] Seevers, P. M., Catedral, F. F. and Daly, J. M. (1971). The role of peroxidase iso enzymes in resistance to wheat stem rust disease. Plant physiol., 48, 353-360.

[34] Shapiro, M., Preisler, H.K. and Robertson, J. L. (1987). Enhancement of baculo virus activity on gypsymoth (Lepidoptera: Lymantriidae) by chitinase. J. Econ. Entomol., 80, 1113-1116.

[35] Shih, S. L., Tsai, W. S., Green, S. K. and Singh, D. (2007). First report of Tomato leaf curl Joydebpur virus infecting chilli in India. Plant Pathol., 56, 341.

[36] Tian, S., Wan, Y., Qin, G. and Xu, Y. (2006). Induction of defense responses against Alternaria rot by different elicitors in harvested pear fruit. Appl. Microbiol. Biotechnol., 70, 729734.

[37] Thaler, J. S., Stout, M. J., Karban, R. and Duffey, S. S. (1996). Exogenous jasmonates simulate insect wounding in tomato plants (Lycopersicon esculentum) in the laboratory and field. J. Chem. Ecol., 22, 1767-1781.

[38] Tiwari, T. P., Bharti, S. K., Kaur, H. D., Dikshit, R. P., Hoondal, G. S., (2005). Synergistic antimicrobial activity of tea and antibiotics. Ind. J. Med. Res.122, 80-84.

[39] Wang, X., Ding, X., Gopalarishnam, B., Morgan, T. D., Johnson, L., White, F. F., Muthurishnan, S. and Kramer, K. J. (1996). Characterization of a $46 \mathrm{kD}$ a insect chitinase from transgenic tobacco. Insect Biochem. Mol. Biol., 26, 10551064.

[40] Wasternack, C. (2007). Jasmonates, an update on biosynthesis, signal transduction and action in plant stress response, growth and development. Ann. Bot.,100 (4), 681697. 